\title{
Occurrence of the Young Thresher Shark Alopias superciliosus Lowe, 1841 (Lamniformes: Alopiidae) in the Northeastern Mediterranean Sea
}

\author{
Deniz AYAS', Hasan Deniz AKBORA ${ }^{1,2 *}$, Burak Ali ÇíçEK² \\ ${ }^{1}$ Faculty of Fisheries, Mersin University, Mersin, Turkey
}

${ }^{2}$ Department of Biological Sciences, Faculty of Arts and Sciences, Eastern Mediterranean University, Famagusta 99628, North Cyprus via Mersin 10, Turkey ORCID ID: Deniz AYAS: https:/ / orcid.org/0000-0001-6762-6284; Hasan Deniz AKBORA: https://orcid.org/0000-0002-6647-866X; Burak Ali ÇiçEK: https:// orcid.org/0000-0001-6144-1721

\begin{tabular}{|c|c|c|}
\hline Received: 02.04.2020 & Published online: 28.04 .2020 & Issue published: 29.06 \\
\hline \multicolumn{3}{|c|}{$\begin{array}{l}\text { Abstract: The Bigeye Thresher Shark Alopias superciliosus Lowe, } 1841 \text { is one of the largest shark species found in the Pacific, } \\
\text { Atlantic, and Indian oceans. They also have started to be seen in the Mediterranean Sea since the 1980s. The presence of two } \\
\text { different species of Thresher sharks in Turkish waters is known, which are A. vulpinus and A. superciliosus. Thresher sharks } \\
\text { can easily be distinguished from other shark species with their big tails. A juvenile female specimen of A. superciliosus with a } \\
\text { total length of } 240 \mathrm{~cm} \text { was caught incidentally in Mersin Bay in January 2020. Essential measurements of the fish were fulfilled } \\
\text { and the specimen was deposited in the Museum of the Systematic, Faculty of Fisheries, Mersin University (catalog number: } \\
\text { MEUFC-20-11-127). This study is the first record of A. superciliosus in Mersin Bay. }\end{array}$} \\
\hline
\end{tabular}

Keywords: Shark conservation, juvenile fish, first record, incidental capture, threatened species.

\section{Kuzeydoğu Akdeniz'de Yavru Sapan Köpekbalığı'nın Alopias superciliosus Lowe, 1841 (Lamniformes: Alopiidae) Bulunuşu}

\begin{abstract}
Öz: Sapan Köpekbalığı (Alopias superciliosus Lowe, 1841), Pasifik, Atlantik ve Hint Okyanusunda büyük köpek balığ1 türlerinden biridir. 1980'lerden itibaren Akdeniz'de de görülmeye başlamışlardır. Türk sularında A. vulpinus ve A. superciliosus türlerinin görüldüğü bilinmektedir. Sapan Köpekbalıkları, büyük kuyrukları ile diğer köpekbalıklarından kolaylıkla ayırt edilebilirler. Toplam uzunluğu $240 \mathrm{~cm}$ olan bir adet yavru-dişi A. superciliosus örneği Ocak 2020'de Mersin Körfezi'nde tesadüfen yakalanmıştır. Örneğin gerekli ölçümleri tamamlandıktan sonra Mersin Üniversitesi, Su Ürünleri Fakültesi, Sistematik Müzesi'nde saklanmıştır (katalog numarası: MEUFC-20-11-127). Bu çalışma Mersin Körfezi'nde A. superciliosus için ilk kayittır.
\end{abstract}

Anahtar kelimeler: Köpekbalığı koruma, yavru balık, ilk kayıt, tesadüfi yakalama, tehdit altındaki türler.

\section{Introduction}

Alopias superciliosus Lowe, 1841 is a large shark species belonging to order Lamniformes, family Alopidae. The common name of $A$. superciliosus is the Bigeye Thresher Shark. In general, thresher sharks can easily be distinguished with their long tails (Compagno, 1984). They are distributed in temperate and tropical waters circumglobal. They are mostly found at depths below 100 $\mathrm{m}$ in the continental shelf regions. Sometimes they can be seen in shallow waters. A. superciliosus feeds on pelagic fishes (Compagno, 2001). Another detailed stomach content analyzes performed in California for $A$. superciliosus showed that barracuda species that belong to the Paralepididae family had the highest rate among the species hunted by A. superciliosus. Moreover, many teleost species, mollusks, and crustaceans are a part of the diet (Preti, Kohin, Dewar, \& Ramon, 2008). Aplacental viviparous breeding occurs in bigeye thresher sharks. The number of juvenile sharks is usually 2, rarely 4. A. superciliosus species mature more slowly than other thresher sharks (Carvalho et al., 2015). During the birth, individuals are around $100-140 \mathrm{~cm}$. It is known that they can reach a total length of $488 \mathrm{~cm}$ (Froese \& Pauly, 2019). It was reported that the males reached reproductive maturity at $279 \mathrm{~cm}$ and the females at $294 \mathrm{~cm}$ (Compagno, 2001).
In a study completed in 2015, A. superciliosus reached $2.5 \%$ by weight among the by-catch of shark species in Turkish waters (Kabasakal, Karman, \& Sakinan, 2017). In Turkey, A. superciliosus was first seen in Gokova in 2005. This was followed by the sample captured in 2007 in Silivri (Kabasakal \& Karhan, 2008) and from Fethiye in 2011 (Kabasakal, Dalyan, \& Yurtsever, 2011). The species was reported from the Gulf of Antalya in 2017 (Gökoğlu, Teker, \& Julian, 2017). This study is the first record of $A$. superciliosus for Mersin Bay.

\section{Material and Methods}

A young A. superciliosus was captured on January 2nd, 2020 by a long-line at a depth of approximately $25 \mathrm{~m}$, Taşucu located in western Silifke (Coordinate: $36^{\circ} 18^{\prime} 17.6^{\prime \prime} \mathrm{N}$, $33^{\circ} 51^{\prime} 41.0^{\prime \prime E}$ ) (Fig. 1). The young specimen (Fig. 2) was a female measuring $240 \mathrm{~cm}$ in total length and weighing 48 $\mathrm{kg}$. This specimen was preserved in $4 \%$ formaldehyde and deposited in the Museum of the Systematic, Faculty of Fisheries, Mersin University (catalog number: MEUFC-2011-127). All diagnostic characteristics and color patterns agree with the descriptions of Compagno (1984) and Compagno (2001). In addition, the morphometric characters determined in Corsini and Sioulas (2009) were measured with dual calipers nearest to $1 \mathrm{~mm}$. 


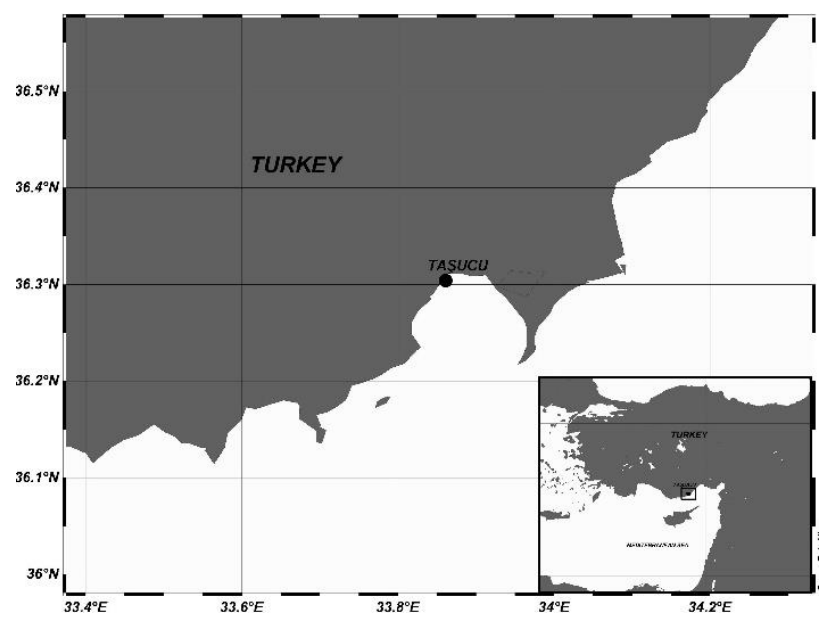

Figure 1. Incidental captured locality $(\bullet)$ for Alopias superciliosus from Mersin Bay

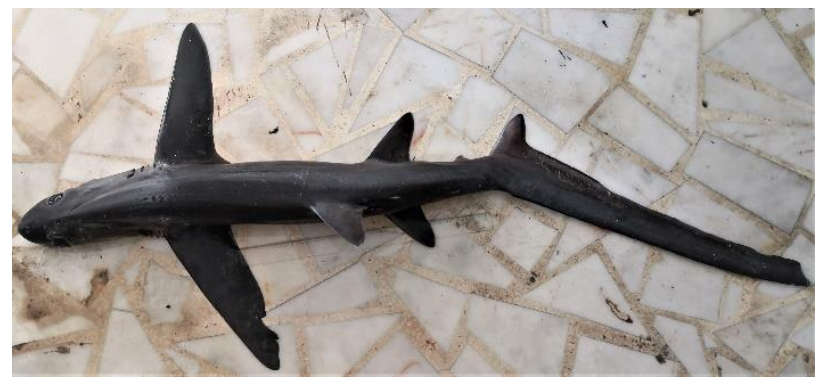

Figure 2. Young female specimen of A. superciliosus from Taşucu coast (NE Mediterranean, Turkey)

\section{Results}

In this study, a juvenile female specimen of Alopias superciliosus was captured incidentally by a fisher using long-line technique. The sample had a total length of 240 $\mathrm{cm}$ and weighing $48 \mathrm{~kg}$. There were 46 teeth in total with three empty tooth roots (Fig. 3). The dental formula of the jaw is 12-12/11-11. The depth of the capture was $25 \mathrm{~m}$, respectively. Moreover, the characteristics of the fish were consistent with the literature. Some distinguishing features for A. superciliosus are as follows. The dorsal extension of the caudal fin is close to the length of the fish other than the tail. The head is flattened from the dorsal and ventral and they have a long nose. The eyes are large and extend to the dorsal part of the head. The pectoral fins are broad-tipped and sickle-shaped. There are a total of 42-
51 teeth in the jaw. The body is brownish-gray in dorsal and lateral and grayish-white in the ventral (Compagno, 1984, 2001).

The date, depth, region, capture technique, gender, length, and weight of the captured sample are shown in Table 1 together with the previous records in Turkish waters. When Turkey records examined for A. superciliosus (Table 1), it is seen that the samples, except Mersin, were mature individuals from Marmara and Aegean regions. The catching depth varies between $12 \mathrm{~m}$ and $110 \mathrm{~m}$. All catches coincide with the period between the last month of winter and the end of spring. The genders of two of the four captured specimens are known and both are female individuals.

Morphometric measurement of two selected studies from the Mediterranean Sea was compared with this study in Table 2. When total length values investigated in detail, the Mersin sample and Dodecanese (Corsini-Foka \& Sioulas, 2009) samples look similar. According to Compagno (2001), only the sample from Mersin is a juvenile individual.

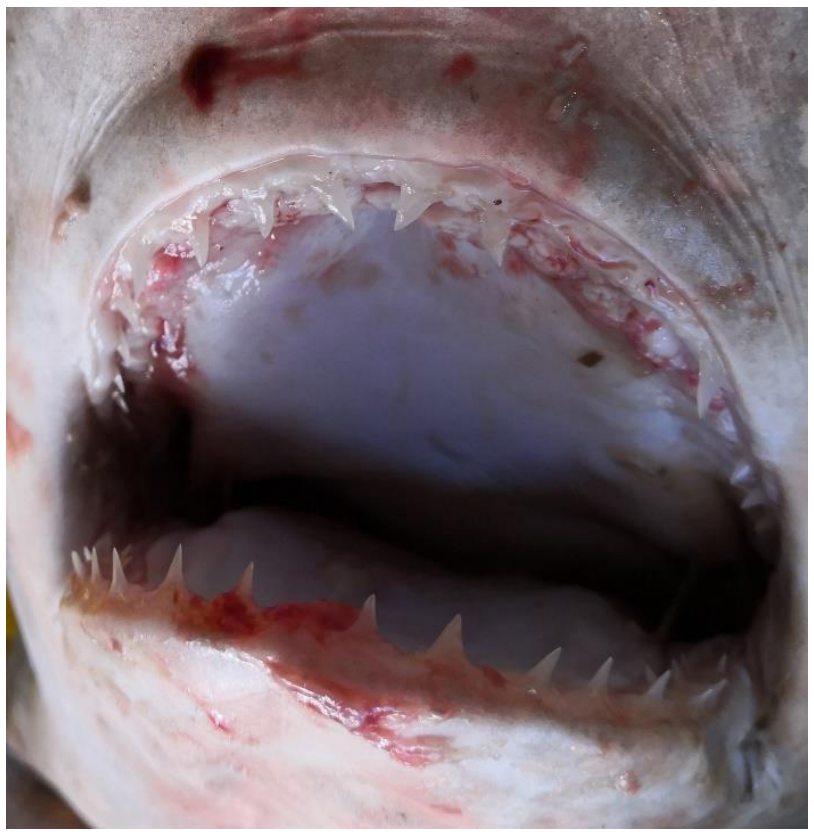

Figure 3. Jaw image of the captured sample.

Table 1. Recent data on Alopias superciliosus in Turkish Mediterranean waters

\begin{tabular}{|c|c|c|c|c|c|c|c|}
\hline Authors & Date & $\begin{array}{l}\text { Depth } \\
\text { (m) }\end{array}$ & Locality & Capture Method & Sex & $\begin{array}{c}\text { Length } \\
(\mathrm{cm})\end{array}$ & Weight (Kg) \\
\hline Kabasakal \& Karhan (2008) & 23th May 2005 & 12 & Gökova & Shrimp-net & N/A & 350 & 150 \\
\hline Kabasakal \& Karhan (2008) & 23rd February 2007 & $\mathrm{~N} / \mathrm{A}$ & Silivri & Purse-seine & $\mathrm{N} / \mathrm{A}$ & 450 & $\mathrm{~N} / \mathrm{A}$ \\
\hline Kabasakal et al. (2011) & 28 th February 2011 & 110 & Fethiye & Trammel-net & 우 & 430 & 300 \\
\hline Gökoglu et al. (2017) & March, April and July 2015 & $600-700$ & Antalya & Bottom trawl, long-line & ㅇ, $\hat{0}$ & $180-299$ & $15.5-65$ \\
\hline This study & $2^{\text {nd }}$ January 2020 & 25 & Taşucu & Trammel net & 우 & 240 & 48 \\
\hline
\end{tabular}


Ayas et al. (2020) Comm. J. Biol. 4(1): 28-31.

Table 2. Comparison of some morphometric measurements of A. superciliosus with two other reports from the Mediterranean Sea.

\begin{tabular}{|c|c|c|c|c|c|c|c|c|}
\hline \multicolumn{3}{|l|}{ This study } & \multicolumn{3}{|c|}{ Corsini-Foka \& Sioulas (2009) } & \multicolumn{3}{|c|}{ Kabasakal et al. (2011) } \\
\hline Mersin Bay & NE Med. & female & Dodecanese & AS & male & Fethiye & AS & female \\
\hline Character & $\mathrm{cm}$ & $\% \mathrm{TL}$ & Character & $\mathrm{cm}$ & $\% \mathrm{TL}$ & Character & $\mathrm{cm}$ & $\% \mathrm{TL}$ \\
\hline TL & 240 & & $\mathrm{TL}$ & 310 & & $\mathrm{TL}$ & 450 & \\
\hline FDFL & 17.9 & 7.4 & FDFL & 27 & 8,7 & FDFL & 41 & 9,1 \\
\hline FDFBL & 13.6 & 5.6 & FDFBL & 21 & 6,8 & FDFBL & 32 & 7,1 \\
\hline PFL & 51.5 & 21.4 & PFL & 62 & 20,0 & PFL & 82 & 18,2 \\
\hline PFBL & 20.1 & 8.4 & PFBL & 21 & 6,8 & PFBL & 30 & 6,7 \\
\hline VFL & 20.6 & 8.6 & VFL & 26 & 8,4 & VFL & 39 & 8,7 \\
\hline VFBL & 15.4 & 6.4 & VFBL & 21 & 6,8 & VFBL & 30 & 6,7 \\
\hline DFVF & 17.8 & 7.4 & DFVF & 23 & 7,4 & DFVF & $\mathrm{N} / \mathrm{A}$ & $\mathrm{N} / \mathrm{A}$ \\
\hline PFVF & 68.9 & 28.7 & PFVF & 77 & 24,8 & PFVF & $\mathrm{N} / \mathrm{A}$ & $\mathrm{N} / \mathrm{A}$ \\
\hline PDL & 87.7 & 36.5 & PDL & 94 & 30,3 & PDL & 128 & 28,4 \\
\hline PVL & 105.3 & 43.9 & PVL & 118 & 38,1 & PVL & 165 & 36,7 \\
\hline PPL & 43.7 & 18.2 & PPL & 45 & 14,5 & PPL & 55 & 12,2 \\
\hline TailL & 103.8 & 43.3 & TailL & 143 & 46,1 & TailL & 217 & 48,2 \\
\hline
\end{tabular}

(Abbreviations used: TL (total length), FDFL (first dorsal fin length), FDFBL (first dorsal fin base length), PFL (pectoral fin length), PFBL (pectoral fin base length), VFL (ventral fin length), VFBL (ventral fin base length), DFVF (distance between dorsal-fin origin and ventral fin origin), PFVF (distance between pectoral fin origin and ventral fin origin), PDL (predorsal length), PVL (preventral length), PPL (pre pectoral length), TailL (tail length) N/A (not available), NE Med. (Northeastern Mediterranean), AS (Aegean Sea)).

\section{Discussion}

In this study, a female juvenile Alopias superciliosus with a total length of $240 \mathrm{~cm}$ was reported from Mersin Bay. Its morphometric measurements were compared with two other selected studies from the Mediterranean Sea. When the results are examined, it is seen that as the sample size increases, some values increase steadily and some decrease in the same way. For example, FDFL, FDFBL, and TailL increase proportional to the size of the fish. On the other hand, PFL, PFBL, PDL, PVL, and PPL values decrease inversely proportional to the fish size. VFL, VFBL, and DFVF values are not affected by the length changes of the fish.

The first records of $A$. superciliosus in the Mediterranean were limited to the Aegean and Marmara regions. All of them were mature individuals. A recent paper of A. superciliosus from Egypt (Farrag, 2017) was a juvenile individual and the individual in our study was a juvenile, too. Two juveniles reported from adjacent regions in a close time range may be an indication that the fish settled in the eastern Mediterranean and began to reproduce.

Alopias superciliosus is shown on the IUCN red list (The International Union for Conservation of Nature's Red List of Threatened Species) as endangered species and their population has been reported to have decreased in number (Walls \& Soldo, 2016). In order to prevent the extinction of this species, conservation activities should be carried out in the Mediterranean region as soon as possible.

It is crucial that these sharks, which can give birth up to 2-4 juvenile sharks at a time (Carvalho et al., 2015), are taken under protection in order not to be extinct. According to the information received from fishers and scuba divers, in the region around the place where Göksu Delta flows into the sea, juvenile sharks are frequently seen. Also, recently a pregnant thresher shark Alopias vulpinus with four pups inside (Ayas, Erguden, Erguden, \& Akbora, 2020b), a juvenile Carcharhinus brevipinna (Ayas,
Çiftçi, \& Akbora, 2019), and another juvenile C. altimus (Ayas et al., 2020a) were caught incidentally near the same region. This area can be a nursing area for many shark species. We are planning to advise this area as a marine protected area after more detailed studies.

Acknowledgements: This study was supported by the Research Fund of Mersin University in Turkey with Project Number: 20172-AP2-2353.

\section{References}

Ayas, D., Çiftçi, N., \& Akbora, H.D. (2019). New Record of Carcharhinus brevipinna (Müller \& Henle, 1839) from Mersin Bay, the Northeastern Mediterranean. Natural and Engineering Sciences, 4, 268-275. https://doi.org/https:// doi.org/10.28978/nesciences.646334

Ayas, D., Ciftci, N., Yalcin, E., Akbora, H.D., Bakan, M., \& Ergüden, D. (2020a). First record of the big nose shark, Carcharhinus altimus (Springer, 1950) from Mersin bay. International Journal of Fisheries and Aquatic Studies, 8(2), 132-136.

Ayas, D., Erguden, D., Erguden, S.A., \& Akbora, H.D. (2020b). Occurrence of the Pregnant and Young Thresher Shark Alopias vulpinus (Bonnaterre, 1788) (Lamniformes: Alopiidae) in the Northeastern Mediterranean Sea. International Journal of Zoological Research, 16, 20-25. https:// doi.org/10.3923/ijzr.2020.20.25

Carvalho, J., Coelho, R., Mejuto, J., Cortés, E., Domingo, A., Yokawa, K., ... Santos, M.N. (2015). Pan-Atlantic distribution patterns and reproductive biology of the bigeye thresher, Alopias superciliosus. Reviews in Fish Biology and Fisheries, 25, 551-568, https://doi.org/10.1007/s11160-015-9389-7

Compagno, L.J.V. (2001). Sharks of the World. An annotated and illustrated catalogue of shark species known to date. Volume 2. Bullhead, mackerel and carpet sharks (Heterodontiformes, Lamniformes and Orectolobiformes). FAO Species Catalogue for Fishery Purposes.

Compagno, L.J. V., (1984). FAO species catalogue. Vol. 4. Sharks of the world. An annotated and illustrated catalogue of sharks species known to date. Part 1. Hexanchiformes to Lamniformes. FAO Fisheries Synopsis. Roma, Italy, 249 pp.

Corsini-Foka, M., \& Sioulas, A., (2009). On two old specimens of Alopias superciliosus (Chondrichthyes: Alopiidae) from the Aegean waters. Marine Biodiversity Records, 2, e72. https://doi.org/10.1017/s175526720900044x

Farrag, M.M. (2017). New record of the bigeye thresher shark, Alopias superciliosus Lowe, 1841 (Family: Alopiidae) from the Eastern Mediterranean Sea. International Journal of Fisheries and Aquatic Studies, 5, 316-318.

Froese, R., \& Pauly, D. (2019). Alopias superciliosus Lowe, 1841 Bigeye thresher. Retrieved from https://www.fishbase.se/summary/Alopiassuperciliosus.html 
Gökoğlu, M., Teker, S., \& Julian, D. (2017). First report of thresher sharks (Alopiidae) in the Gulf of Antalya. Iranian Journal of Fisheries Sciences, 16, 1108-1113.

Kabasakal, H., Dalyan, C., \& Yurtsever, A. (2011). Additional Records of the Bigeye Thresher Shark Alopias Superciliosus (Lowe, 1839) (Chondrichthyes: Lamniformes: Alopiidae) From Turkish Waters. Annales, Series Historia Naturalis, 21, 143-148.

Kabasakal, H., \& Karhan, S.Ü. (2008). On the occurrence of the bigeye thresher shark, Alopias superciliosus (Chondrichthyes: Alopiidae), in Turkish waters. Marine Biodiversity Records, 1, e69. https://doi.org/10.1017/s1755267207007452

Kabasakal, H., Karman, S.Ü., \& Sakinan, S. (2017). Review of the distribution of large sharks in the seas of Turkey (Eastern Mediterranean). Cahiers de Biologie Marine, 58, 219-228. https://doi.org/10.21411/CBM.A.96D9F948

Preti, A., Kohin, S., Dewar, H., \& Ramon, D. (2008). Feeding habits of the bigeye thresher shark (Alopias superciliosus) sampled from the California-based drift gillnet fishery. California Cooperative Oceanic Fisheries Investigations Report, 49, 202-211.

Walls, R.H.L. \& Soldo, A. (2016). Alopias superciliosus. IUCN Red List Threatened Species. Retrieved from https://www.iucnredlist.org/species/161696/16527729 